Отримано: 29 липня 2019 року

Прорецензовано: 16 вересня 2019 року

Прийнято до друку: 23 вересня 2019 року

e-mail: weno4ek@tut.by

DOI: $10.25264 / 2519-2558-2019-7(75)-114-116$
Khorsun I. O. Specificity of belarusian literary translation. Наукові записки Національного університету "Острозька академія»: серія «Філологія». Острог: Вид-во НаУОА, 2019. Вип. 7(75), жовтень. С. 114-116.

\title{
SPECIFICITY OF BELARUSIAN LITERARY TRANSLATION
}

The article deals with the problem of translation as a culturological phenomenon, assessment criteria of poetic work, types of poetic translation and its functions. The article focuses on translation of English poetry into the Belarusian language. Verse form, rhythm, melody, rhyming system create difficulties for the translator, because the success of the translation of the poetic text is determined by matching not only the content but also the poetic form of the original. The translator must focus on the objectively existing compliance and the relationship between the languages that are exceptional in the languages that belong to different groups. The transmission of expressive means requires distinctive changes on lexical and grammatical and (or) syntactic levels. Only high-quality translation is able to enrich the literature in the ideological-thematic and genre-stylistic sense, become one of the elements of national literary context.

Key words: literary translation, cultural element, linguistic means, reception, interlinear translation, original work.

\author{
Хорсун Ірина Олександрівна, \\ кандидат філологічних наук \\ Гомельський державний університет імені Ф. Скорини
}

\section{СПЕЦИФІКА БІЛОРУСЬКОГО ХУДОЖНЬОГО ПЕРЕКЛАДУ}

Статтю присвячено проблемі перекладу як культурологічної явища, критеріям очінки оригінального поетичного твору, видом віршованого перекладу і його функиій. Особливо розглядається переклад англомовної поезії на білоруську мову. Віршована форма, ритміка, мелодика, система римування створюють певні труднощі для перекладача, оскільки успіх перекладу поетичного тексту визначається відповідністю не тільки змісту, а й поетичній формі оригіналу. Перекладач повинен орієнтуватися на об'єктивно існуючі відповідності і співвідношення між мовами, які стають винятковими в неблізкароднасних мовами. Передача образотворчих засобів вимагає відмінних пересозданія на лексичному, граматичному $і$ (або) синтаксичному рівнях. Тільки переклад високого ступеня якості здатний збагатити літературу в ідейно-тематичному і жанрово-стилістичному сенсі, стати одним з елементів національного літературного контексту.

Ключові слова: художній переклад, елемент культури, засоби мови, рецепиія, підрядковий переклад, оригінал.

The rise of the culture of peoples, including the Belarusians, strengthening the relationship between them, the desire to know more deeply and fully the best that created and generated by progressive mankind are remarkable phenomena of our time. In the process of intercultural communication a distinctive role belongs to literary translation. Literary translation is a living thing with rich theory and practice.

The creators of the theory of translation were the translators themselves; the main problem of their discussion was the degree of approximation to the original translation.

In the XVI century French poet and translator Etienne Dolet (1509-1546) published a treatise "The way of good translation from one language into another" ("La manière de bien traduire d'une langue en l'autre"), in which he proposed the five principles of translation: to understand the content and intention of the author; to be proficient in the two languages; to avoid literal translation; to use the actual speech patterns; to transmit the tone of the text [4, p. 155].

Notable theorists and interpreters of the XVII century Abraham Cowley, Sir John Denhom and John Dryden distinguished three types of translation: a metaphrase (literal translation), a paraphrase (paraphrasing), and an imitation. J. Denhom believed that the sense is eternal and universal, it is easily transmitted through languages and cultures, regardless of the different semantic context and different cultural discourse [6].

In 1790 Arthur Walter Tyler wrote a treatise "Principles of Translation", in which he proposed the three main principles of translation. They are as follows: the translation must fully convey the content of the original; the style and manner must be kept the same; the translation should be read as easily as the original [11].

It was only in the middle of the XX century when the foundations of scientific theory of translation were laid. For a long time the translation had been considered a non-linguistic science in the west. This was due to the development of many linguistic aspects, such as comparative linguistics, synchronic description of languages, communicative language theory.

Among the Soviet and Western theorists there should be stated G. Gachechiladze ("Literary translation and literary relationship", 1972), R. Jakobson ("Linguistic Aspects of Translation Theory”, 1978), S. Florin (“Untranslatable in translation”, 1980), A. Lilova ("Introduction to the general theory of translation", 2000). They have developed and are still developing a variety of problems such as match types, functional styles and translation, translation methods, ways of transmission of different types of meanings [90, p.7-8]. In the 1950s the first substantial works on the theory of translation into Russian appeared. Among the authors there is E. Retsker ("Theory and practice of translation", 1973), L. Barhudarov ("Language and Translation (General and special theory of translation)", 1975), A. Fedorov ("Fundamentals of general theory of translation", 1983), later V. Krupnov ("Lexicographical aspects of translation", 1987), A. Shveytser ("Theory of translation (status, problems and aspects)", 1988), V. Komissarov ("Theory of translation (linguistic aspects)" 1990). The XXI century brought the works by E. Breus ("Fundamentals of the theory and practice 
of translation”, 2000), V. Kabakchi (“Underinvestigated form of translation: “internal translation”, 2000) and V. Vinogradov ("Introduction to Translation (general and lexical issues)", 2001.

More than once, scientists from different countries have resorted to the actualization of the problems of translation as a cultural phenomenon. Russian researchers L.K. Latyshev and A.L. Semenov examined the translation not only as a substitute for the language, but also as a functional replacement of elements of culture [8, p. 108]. The translator must learn the word contextually, analyze the synthesis of linguistic and stylistic, cultural and aesthetic units, as it is national feature of a translator that must be shown in the translation [5, p. 147]; since the problem of national specificity of art and nationality problem form the national consciousness. Researcher G. Lilova emphasized that the task of every translator is "to find and understand the essence of the national distinctive and specific; in the successful transfer the specific, original and national foundation of works does not disappear, and that is seen as one of the basic principles of creative translation work" [9, p. 103-104]. German writer I.R. Becher pointed out that "the creation of a high transfer culture contributes to the national literature growth and the awareness of its own national character" [2, p. 93]. Thus, literary translation is the most representative form of contact between national literatures.

In the early 1990s in the Belarusian theory the translation was regarded as a valid nation forming factor [12]. V. Ragoisha, I. Charota, N. Dzianisava, S. Skamarohava and other researchers on theory and practice of literary translation addressed the problem of reception and interpretation of the translator as a collaborator. In this connection the Belarusian comparativist I. Shablovskaya rightly notes: "We must recognize that the energy of the literary interaction in Belarus is barely perceptible. Very few works of the world classics have been translated into Belarusian, both Western and Eastern literature works are presented only fragmentary, Russian literature is the exception... Belarusian situation is thus indicative of the limitations of the perception of the world literature" $[15$, c. 190$]$.

What place is given to the Belarusians in the positions among the peoples of Europe? M. Bagdanovich took care to make the Belarusian poetry "more European" but he had no doubt that the European poetry had a Belarusian branch. Genuine poetics of Verlen's poem of M. Bagdanovich, the allusions of Dante in Kupala's works, unsurpassed translations of William Shakespeare's sonnets performed by U. Dubouka, all this reflects the relationship between literatures of different genetic, typological and contact features. Besides Ya. Semyazhon, who translated the works from 34 different languages, we can state other compatriots' translations from Byron, Goethe, Dante. R. Baradulin illustrated a new transfer school, interpreted the fragments of Scripture.

Every nation has its own well-developed art system, as well as translation has its creativity culture. The problem of transmission of "national" component is due to national and cultural component. The knowledge of folk traditions, peculiarities of attitude, the so-called situational realities performs an important role. For example, a night in the perception of Europeans is definitely associated with sleep, cold; for the eastern residents a night is coordinated with the organized peace. These perceptions differ due to various embedded senses of the aesthetic outlook of every people, so such situational realities require specific comments from the translator.

Researcher I.S. Alexeyeva states: “... the representatives of different cultures, who have different historical and social experience, understand freedom in different ways. Americans, Russians, Belarusians, Germans and Chinese have different notions of freedom. For example, to a Russian and a Belarusian freedom is primarily the lack of any obligations, a right to choose what to do and when, the absence of external pressure; for a German freedom is primarily a legal warranty of their rights, clear alignment of legal system, material security, and Russian "freedom" is rampant for him. Such cases often lead to misunderstanding. If these contacts are oral, then an interpreter, in addition to the translation of the text is assigned to be an adviser on cross-cultural communication, and if a written text is translated, it is necessary to make comments or notes (initiated by the translator) to the text" $[1, \mathrm{p} .11-12]$.

The criteria for assessing the original poetic work is a subjective taste of a reader; some readers like the work, others don't, but a poetic translation that the reader regards the same as the original work, has a different criterion. A translator is a transmission centre, and the criteria for evaluating whether it is a success or a failure is the original. The fuller and more accurate the poetic complex is expressed in the translation, the better. What are the specifics of literary translation? A translation, even the most perfect, can never replace the original, it can only give an idea of the original [16].

The feeling of the nature of thinking of the poet is one of the main tasks of a translator. Thus, M. Bagdanovich wrote a poem based on the original of Verlaine's work, but did not translate the original work with interlinear. Belarusian literary critic V. Ivashyn on the dialogism of M. Bagdanovich's way of thinking wrote the following: "The poet was able to deeply empathize the close, the dear to himself in other cultures, to find something to his soul there. Sensitivity to the "foreign and strange" as his very own and dialogism are the hallmark of his poetics, artistic thinking and creative stimulus and way of perceiving traditions" [7, p. 259]. Combining a kind of transparency and enticing feeling reticence is the way to a real artistic phenomenon.

Translations from English literature into the Belarusian language has started recently; the translation tradition from English into other languages goes to distant centuries, the Belarusians got interested in English literature only in 1925, when Yuri Gauruk translated one of the comedies of William Shakespeare. From the same period we should recall the famous Uladzimir Dubouka, the author of translations of William Shakespeare's sonnets. Yazep Semyazhon was another figure among the English poetry interpreters. Robert Burns' poems became clear to Belarusian readers thanks to Ya. Semyazhon, who also left a great legacy in the translation from different literatures $[17$, p. 8$]$. These and other interpreters were able to convey to the reader in a live form, sincerely and clearly the strength and the character of the literature of other nations.

No one doubts that it is not enough for a translator to speak and understand two languages, they need to have an idea of the country, i.e. its history, geography, lifestyle and mentality of the people. And even, as noted by Alena Tabolich, knowing all this, the translators can not fulfill their task in the best sense of the word, for the reason that they do not have a "creative bone". This is especially true while interpreting poetry, where a literal retelling is inadmissible because the translation of a poem requires penetration into the content and the form, where everything is connected in one flight: the thought, the turns, the wingspan and the hope for the reader's understanding [17, p. 10]. So we need to understand the theory of translation, which can not be ignored, because it helps the translator to improve their technique, notice their mistakes and to compare themselves with others. Some works by V. Ragoysha, L. Barshcheusky, A. Yaskevich, K. Sherman are dedicated to the translation from a literary point of view, but there is almost no linguistic works, except for the works by T. Lavyshand A. Shydlousky. As the analysis of the original and the translated 
works shows, there are errors and inaccuracies, because intuition and practice is quite insufficient to reach the top in the creative work. The theory of translation gives it all to the future creator.

The poetic translation is true to be considered the top of the translation skills, because in addition to the content it is supposed to transfer as much as possible in the terms of the form. The interpreter should keep in mind the author's images that make up a kaleidoscope of feelings, thus the main task of the translator is to transfer these images with appropriate means that are able to evoke appropriate feelings in the reader's mind and soul, as well as provide an opportunity to touch the world's thought. The interpreters translate the poems into their native language to acquaint the society with the cultural achievements of other nations and people. The reader believes the interpreter, looks at the phenomenon through their eyes, sees the poem as the translator submits. Hence there is a double responsibility of the interpreter, i.e. to the author and the reader.

There are two types of poetic translation: free and accurate. Free translation turns out to be a new product, especially if the translator interprets not only the content but also the rhythm, the tone. The accurate translator provides not only a complete picture of the action (taking into account all the details of the text), but also gives the translation some personal harmony that the reader feels through their own reality. Such a transfer is possible, if the interpreter is impregnated with the era when the work was created, with the nature of the country, with the nuances of the author's life and activity. The accurate translator tries to convey everything, i.e. the formal features, every small part of the images, philosophical orientation and the peculiarities of the era.

As an example, it is essential to quote Mikalai Zabalotsky and his commands to the translator [10, p. 326-328]:

- the translation is good if it does not exceed the balance between the original;

- the translator must be able to combine the measure of accuracy with the measure of naturalness;

- a good poet can be a bad translator, but a bad poet can not therefore be a good translator;

- translation is perceived as an examination for the richness of the interpreter's vocabulary;

- it is not approved to entertain readers where they need to cry;

- the translated work is not the property of the translator.

The famous Russian poet Nikolai Gumilyov offered three ways of interpreting the poems: amateur, professional and redone, in which the identity of the translator is stronger.

The two main functions of the poetic translation, cognitive and aesthetic, can be realized only when the translator remembers the conditions which N. Gumilyov drew attention to: the number of lines, the size and the meter, the alternation of rhymes, the type of transferring one line to another, the nature of rhymes, vocabulary peculiarities, the type of comparison, special techniques, tone transitions and others [10, p. 81-82].

As Professor V.P. Ragoysha rightly observes, even the translation from closely related languages has specific difficulties. The genetic proximity of phonetic, lexical and grammatical systems of the Russian and Belarusian languages involves both similarities and differences, which the translators usually forget. If there is a task set to translate from English, German or French, the translator must be a master of the language to be able to penetrate into every image and convey the beauty and does not deprive the work of its distinctive features [13].

I. Charota draws attention to the lack of certainty in the question on transferability, i.e, a general possibility to fully convey all the meanings of a certain text, especially poetic. The researcher further notes "The translator in prose is a slave, the translator in poetry is a rival" [3, p. 16]. The similar view is also expressed by A. Razanau: "While translating the poetry the interpreters should follow the poetry itself, i.e. not to translate the very words or stanza, but to transfer the meaning, the sense of a sound and the spiritual sense" [14].

Thus, each transfer can be only a variant of the original. The higher the artistic quality of the translation, the more it will be the independent work, that is, undisturbed in all its components. It must be remembered that the transfer of a poetic work is done by means of a language. If the language is changed, the form is changed too. The main task is to preserve the poetic flavor of the original, its spontaneity and freshness.

\section{Literature:}

1. Alexeeva I. S. Vvedenie v perevodovedenie: ucheb. posobie dlya stud. filol. i lingvist. fak. vy'ssh. uch. zavedenij. SPb. : Filologicheskij fakul'tet SPbGU, M.: Izdatel'skij centr Akademiya, 2004. $352 \mathrm{~s}$.

2. Beher I. R. O literature i iskusstve. 2-e izd. M. : Hudozh. lit., 1981. 527 s.

3. Charota I. A. Teoryya i praktyka mastaczkaga perakladu. Vuche'bny dapamozhnik pa kursu "Teoryya i praktyka perakladu". Minsk : Beldzyarzhuniversite't, 2010. $89 \mathrm{~s}$.

4. Dolet E. La manière de bien traduire d'une langue en l'autre. Lyon, 1540. Cary E. Les Grands traducteurs français. Genève, 1963. $640 \mathrm{p}$.

5. Gachechiladze G. Hudozhestvenny'j perevod i literaturny'e vzaimosvyazi. M. : Sovetskij pisatel', 1980. $253 \mathrm{~s}$.

6. Istoriya perevoda / Perevod v zapadnom mire. - Per. s angl. vypolnen v «Prima Vista». 1999. URL: http://www.primavista.ru/rus/ catalog/istoriya perevoda. - Date of access : 02.11.2013.

7. Ivashy’n V.U. U kante'ksce mastaczkih kul'tur. Polymya. 1998. № 12.

8. Laty'shev L. K., Semyonov A. L. Perevod: teoriya, praktika i metodika prepodavaniya: ucheb. posobie dlya stud. perevod. fak. vy'ssh. ucheb. zavedenij. M. : Akademiya, 2003. $192 \mathrm{~s}$.

9. Lilova A. Vvedenie v obshhuyu teoriyu perevoda: monogr.; perevod s bolg. L.P. Lixachyovoj. M. : Vy'sshaya shkola, $1985.153 \mathrm{~s}$.

10. Makedonov A. V. Nikolaj Zaboloczkij: zhizn', tvorchestvo, metamorfozy'. L. : Sovetskij pisatel', 1987. $365 \mathrm{~s}$.

11. Pervye teoretiki perevoda / Printsipy perevoda A. Tajler. 2009. URL: http://winref.ru/000_uchebniki/02800_literatur/7-9/321.htm. Date of access : 02.11.2013.

12. Ragojsha V. Peraklad yak nacyyatvaral'ny' faktar. Belarusika = Albaruthenika: Kn. 1 / Re'd. A. Mal'dzis i insh. Minsk, 1993. S. $225-230$.

13. Ragojsha V.P. Problemy perevoda s blizkorodstvennyh yazykov. Minsk : Izd-vo BGU, 1980. S. 61-66.

14. Razanau A. Palyavanne u rajskaj daline. Minsk : Mastaczkaya litaratura, 1995. S. 255.

15. Shablouskaya, I.V. Susvetnaya litaratura u belaruskaj prastory: Reczepcyya. Typalogiya. Kantakty. Minsk : Rady`yola-plyus, 2007. $302 \mathrm{~s}$.

16. Stankevich, R. Majsterstva perakladu. Zvyazda, 24 studz. 1981. S. 4.

17. Tabolich,A. Tayamnicy mastaczkaga perakladu: English $\leftrightarrow$ Belarusian. Minsk : Bel. knigazbor, 2004. $148 \mathrm{~s}$. 